\title{
PENGARUH PROMOSI JABATAN DAN MOTIVASI KERJA KARYAWAN TERHADAP KINERJA KARYAWAN PADA PT PLN (PERSERO) WILAYAH SUMUT
}

\author{
Nurasnita ${ }^{1)}$, \& Lokot Muda Harahap ${ }^{2)^{*}}$ \\ 1) Fakultas Ekonomi, Universitas Negeri Medan \\ 2) Fakultas Ekonomi, Universitas Negeri Medan \\ E-mail : lokotmd@gmail.com
}

\begin{abstract}
Abstrak
Penelitian ini bertujuan untuk mengetahui dan menjelaskan pengaruh promosi jabatan terhadap motivasi kerja karyawan, pengaruh promosi jabatan terhadap kinerja karyawan, dan pengaruh motivasi kerja karyawan terhadap kinerja karyawan pada PT. PLN (Persero) Wilayah Sumut. Data yang digunakan dalam penelitian ini adalah data promosi jabatan, motivasi kerja karyawan, dan kinerja karyawan. Jumlah populasi dalam sampel ini adalah karyawan PT PLN (Persero) Wilayah Sumut sebanyak 173 orang, dan sampel yang diambil dalam penelitian ini adalah 173 responden, dengan teknik pengambilan sampel adalah total sampling. Dengan demikian hipotesis dalam penelitian ini diterima yaitu terdapat pengaruh Promosi Jabatan terhadap Motivasi Kerja Karyawan, terdapat pengaruh Promosi Jabatan terhadap kinerja karyawan, terdapat pengaruh Motivasi Kerja Karyawan terhadap kinerja karyawan.
\end{abstract}

\section{Kata kunci : Promosi Jabatan, Motivasi Kerja,, Kinerja Karyawan}

\section{Abstract}

This study aims to identify and explain the effect of job promotion on work motivation, the effect of job promotion on employees performance, and the effect of work motivation to employees performance at PT. PLN (Persero) Wilayah Sumut. Data in this research are data of job promotion, work motivation, and employee performance. The population used in this study is employee of PT PLN (Persero) Wilayah Sumut was 173 person, with used total sampling. The hypothesis in this study is accept that there are effect of job promotion on work morivation, there is the influence of job promotion on employees performance, there is the influence of work motivation on employees performance.

\section{Keywords: Job Promotion, Work Motivation, Employee Performance}

\section{PENDAHULUAN}

Suatu perusahaan dalam melaksanakan kegiatannya, baik perusahaan yang bergerak di bidang industri, perdagangan, maupun jasa akan berusaha mencapai tujuan yang telah ditetapkan sebelumnya. Suatu hal yang penting yaitu bahwa keberhasilan berbagai aktivitas di dalam perusahaan untuk mencapai tujuan bukan hanya tergantung pada keunggulan teknologi, dana operasi yang tersedia, sarana ataupun prasarana yang dimiliki, melainkan juga tergantung pada aspek sumber daya manusia. Karena tanpa adanya peran sumber daya manusia di dalam perusahaan, kegiatan operasional perusahaan tidak akan dapat berjalan dengan baik. Perusahaan yang baik itu harus dapat bekerja dengan lebih efisien, efektif, inovatif dan produktif. 
Tingkat kompetisi yang tinggi akan memacu setiap perusahaan untuk dapat mempertahankan kelangsungan hidup perusahaan tersebut.

Mengingat begitu pentingnya peranan sumber daya manusia dalam suatu perusahaan, sudah sepatutnya jika perusahaan memperhatikan aspek-aspek kerja yang berkaitan dengan sumber daya manusia. Karyawan yang memiliki motivasi kerja yang kuat merupakan keunggulan bagi suatu perusahaan. Hal ini tentunya dapat meningkatkan kinerja karyawan. Pada dasarnya, perusahaan bukan saja mengharapkan karyawan yang memiliki tingkat intelektual tinggi, tetapi yang terpenting mereka mau bekerja giat dan berkeinginan untuk mencapai hasil kerja yang optimal.

PT PLN (Persero) Wilayah Sumut merupakan perusahaan Badan Usaha Milik Negara (BUMN) yang bergerak di bidang jasa pelayanan pelistrikan di Indonesia, khususnya di wilayah Sumatera Utara. Bagi perusahaan, peran sumber daya manusia disini sangatlah penting dalam mengoperasikan perusahaan agar dapat mencapai tujuan dari perusahaan. Oleh karena itu, PT PLN (Persero) Wilayah Sumut selalu mengupayakan agar karyawannya mendapatkan kepuasan dalam bekerja agar kinerjanya juga meningkat. Melalui wawancara pendahuluan penulis dengan karyawan bidang sumber daya manusia PT PLN (Persero) Wilayah Sumut mengenai bagaimana kinerja karyawan selama ini, beliau mengatakan bahwa kinerja karyawan dinilai masih mengalami fluktuasi dalam menjalankan tugasnya. Hal ini bisa terjadi dikarenakan ketidakpuasan karyawan akibat kurang terpenuhinya kebutuhan, keinginan, rasa aman, serta lingkungan kerja yang kurang baik sehingga dapat menurunkan motivasi kerja karyawan yang berdampak pada menurunnya kinerja karyawan yang justru dapat merugikan kedua belah pihak.

Sebagai karyawan yang menggerakkan segala aktivitas perusahaan, karyawan akan terus bergerak maju untuk memperoleh keberhasilan. Seseorang yang bekerja di perusahaan pada umumnya akan menjadikan dirinya untuk menjadi lebih baik lagi dari sebelumnya. Adanya kesempatan untuk mengembangkan diri mendorong seorang karyawan untuk berusaha meningkatkan kinerjanya menjadi lebih baik dari sebelumnya. Kesempatan untuk maju dari karyawan itulah yang digunakan perusahaan untuk menaikkan karir karyawan yang berprestasi. Dalam perusahaan menaikkan karyawan yang berprestasi disebut dengan promosi jabatan.

Promosi jabatan di dalam suatu perusahaan sangat berperan penting dalam memotivasi karyawan agar lebih giat dalam bekerja. Dalam melaksanakan program promosi jabatan, perlu di adakan kriteriakriteria terlebih dahulu. Kriteria tersebut hendaknya di jadikan sebagai standar dalam menetapkan siapa yang berhak untuk di promosikan. Dengan pelaksanaan promosi jabatan, kebutuhan akan adanya jenjang karir yang lebih baik akan terwujud.

Promosi jabatan di PT PLN (Persero) Wilayah Sumut biasanya dilaksanakan dua kali dalam setahun. Jadi setiap enam bulan sekali di adakan seleksi bagi karyawan yang 
menginginkan peningkatan jabatan. Dalam proses seleksi ini biasanya ada beberapa tahap yang harus dilaksanakan oleh karyawan seperti tes tertulis dan wawancara.

Berdasarkan hasil wawancara pendahuluan dengan karyawan bidang sumber daya manusia PT PLN (Persero) Wilayah Sumut, yang menjadi syarat utama bagi karyawan yang ingin naik jabatan adalah prestasi kerja, senioritas, serta tingkat pendidikan karyawan. Berdasarkan hasil wawancara peneliti dengan beberapa karyawan, jumlah jabatan/posisi yang dipromosikan dalam setahun itu tidaklah banyak, sementara proses promosi jabatan yang dilaksanakan oleh pihak PT PLN (Persero) Wilayah Sumut ini di tujukan bagi karyawan PT PLN (Persero) yang memenuhi syarat di seluruh kantor cabang se-Sumatera Utara. Hal ini lah yang menjadi faktor penghambat promosi jabatan di PT PLN (Persero) Wilayah Sumut, yaitu banyaknya jumlah karyawan yang ada dalam perusahaan, sedangkan posisi atau jabatan yang di promosikan oleh perusahaan jumlahnya tidaklah banyak. Jumlah karyawan tentu mempengaruhi manajemen karir yang ada dan menurunkan motivasi kerja karyawan, sebab semakin banyak jumlah pegawai maka semakin ketat persaingan untuk menduduki jabatan, demikian pula sebaliknya.

Dalam perencanaan sumber daya manusia faktor motivasi juga tidak kalah penting dalam meningkatkan daya saing perusahaan. Karena motivasi merupakan salah satu pendorong bagi seseorang untuk melaksanakan suatu kegiatan guna mendapatkan hasil yang terbaik. Oleh karena itulah tidak heran jika seorang karyawan yang mempunyai motivasi kerja yang tinggi biasanya mempunyai kinerja yang tinggi pula. Dan sebaliknya jika seorang karyawan yang memiliki motivasi yang rendah maka memiliki kinerja yang rendah pula. Untuk itu motivasi karyawan perlu dibangkitkan agar karyawan dapat menghasilkan kinerja yang baik (Imlawal dan Winarningsih, 2016:2).

Motivasi yang rendah cenderung akan melemahkan semangat karyawan dalam bekerja. Oleh karena itu pimpinan pada kantor PT. PLN (Persero) Wilayah Sumut harus memperhatikan hal ini, karena motivasi yang diberikan ke karyawan dinilai masih kurang. Dalam hal ini motivasi para karyawan pada PT. PLN (Persero) Wilayah Sumut di anggap belum maksimal, terbukti dari hasil wawancara peneliti dengan beberapa karyawan PT. PLN (Persero) Wilayah Sumut bahwa beberapa karyawan merasa ketika ia sudah berhasil mencapai target berdasarkan tanggung jawab yang diberikan, namun perusahaan dinilai masih kurang memberi apresiasi atau penghargaan khusus sehingga menyebabkan karyawan merasa seperti kurang dihargai oleh perusahaan. Salah seorang kayawan mengatakan bahwa selama 3 tahun terakhir ia merasa sudah mengerjakan semua tugas yang diberikan kepadanya, namun hingga saat ini ia belum pernah dipromosikan ke jabatan yang lebih tinggi. Hal ini sangat di khawatirkan karena kedepannya bisa berdampak pada meningkatnya kelambanan kerja karena perasaan kurang dihargai tersebut yang justru dapat merugikan kedua belah pihak. 


\section{KAJIAN PUSTAKA \\ Kinerja Karyawan}

Kinerja karyawan merupakan suatu hal yang sangat penting dalam usaha organisasi mencapai tujuannya, sehingga berbagai kegiatan harus dilakukan organisasi tersebut untuk meningkatkannya. Kinerja karyawan mempengaruhi seberapa banyak mereka memberikan kontribusi kepada perusahaan. Mangkunegara (2005:9) mengemukakan bahwa istilah kinerja berasal dari kata job performance atau actual performance (prestasi kerja atau prestasi sesungguhnya yang dicapai seseorang) yaitu hasil kerja secara kualitas dan kuantitas yang dicapai oleh seseorang pegawai dalam melaksanakan tugasnya sesuai dengan tanggung jawab yang diberikan kepadanya.

\section{Promosi Jabatan}

Pengertian promosi jabatan sebagaimana yang dikemukakan oleh Khadarisman (2012:124) yaitu suatu proses kegiatan perpindahan pegawai dari suatu jabatan ke jabatan lain yang mempunyai status serta tanggung jawab yang lebih tinggi. Pada umumnya dengan promosi ini, di ikuti dengan peningkatan kompensasi (gaji dan lain-lain) walaupun tidak selalu demikian. Untuk promosi tersebut perlu ditetapkan syarat-syarat tertentu. Syarat-syarat tersebut pada umumnya ditetapkan untuk promosi, antara lain prestasi kerja, pengalaman, pendidikan, kemampuan, kompetensi, dan lainnya.

\section{Motivasi Kerja Karyawan}

Terdapat banyak pengertian tentang motivasi. Diantaranya adalah menurut Heller (dalam Wibowo, 2007:378) yang menyatakan bahwa motivasi adalah keinginan untuk bertindak. Ada pendapat bahwa motivasi harus di injeksi dari luar, tetapi sekarang semakin dipahami bahwa setiap orang termotivasi oleh beberapa kekuatan yang berbeda. Di pekerjaan kita perlu memengaruhi bawahan untuk menyelaraskan motivasinya dengan kebutuhan organisasi.

\section{METODE PENELITIAN}

Penelitian ini di laksanakan di PT. PLN (persero) Wilayah Sumut yang beralamat di Jalan Yos Sudarso No. 284, Glugur Kota, Medan. Jadwal waktu penelitian dilakukan pada bulan Juli 2017. Adapun populasi data penelitian ini adalah karyawan yang sudah pernah di promosi pada PT PLN (Persero) Wilayah Sumut yang berjumlah 173 karyawan. Teknik pengambilan sampel yang di pakai dalam penelitian ini ialah teknik total sampling. Seluruh populasi sebanyak 173 karyawan digunakan untuk pengambilan sampel. Dimana dalam penelitian ini 30 orang akan digunakan untuk uji validitas dan uji reliabilitas, sisanya 143 orang akan digunakan untuk pengambilan sampel.

Penelitian ini menggunakan metode path analysis, dalam path analysis terdapat 2 variabel yaitu variabel eksogen dan variabel endogen. Adapun yang termasuk Variabel eksogen yaitu Promosi Jabatan (X1), sedangkan yang termasuk variabel endogen yaitu Motivasi Kerja (X2) dan Kinerja Karyawan (X3).

\section{HASIL DAN PEMBAHASAN Hasil Penelitian}

Pengujian linieritas digunakan dengan uji $\mathrm{F}$ (Liniearity) pada taraf 
signifikan 5\%. Apabila hasil yang diperoleh dibawah nilai 0,05 maka dapat disimpulkan linier. Begitu sebaliknya, jika hasil yang diperoleh diatas nilai 0,05 dapat disimpulkan tidak linier. Dari hasil output SPSS, dapat diketahui bahwa nilai sig. dari linearity adalah 0,020 dan nilai sig. dari deviation from linearity adalah 0,797 . Artinya nilai sig. linearity lebih kecil dari $0,05(0,020<0,05)$ dan nilai sig. deviation from linearity lebih besar dari $0,05(0,797>0,05)$. Dengan demikian dapat disimpulkan bahwa hubungan antara variabel Promosi Jabatan dan variabel Motivasi Kerja adalah linier.

Dari hasil output SPSS, dapat diketahui bahwa nilai sig. dari linearity adalah 0,000 dan nilai sig. dari deviation from linearity adalah 0,063 . Artinya nilai sig. linearity lebih kecil dari $0,05(0,000<0,05)$ dan nilai sig. deviation from linearity lebih besar dari $0,05(0,063>0,05)$. Dengan demikian dapat disimpulkan bahwa hubungan antara variabel Promosi Jabatan dan variabel Kinerja Karyawan adalah linier. Dari hasil output SPSS, dapat diketahui bahwa nilai sig. dari linearity adalah 0,015 dan nilai sig. dari deviation from linearity adalah 0,650 . Artinya nilai sig. linearity lebih kecil dari 0,05 $(0,015<0,05)$ dan nilai sig. deviation from linearity lebih besar dari 0,05 $(0,650>0,05)$. Dengan demikian dapat disimpulkan bahwa hubungan antara variabel Motivasi Kerja dan variabel Kinerja Karyawan adalah linier.

Untuk

selanjutnya

berdasarkan diagram jalur dapat ditentukan besarnya koefisien pengaruh langsung, pengaruh tidak langsung dan pengaruh total antar variabel. a. Pengaruh Langsung

1) Pengaruh promosi jabatan $\left(\mathrm{X}_{1}\right)$ terhadap motivasi kerja karyawan $\left(\mathrm{X}_{2}\right)$ ditunjukkan oleh $\rho X_{2} X_{1}$ sebesar 0,636 atau $63,6 \%$.

2) Pengaruh promosi jabatan $\left(\mathrm{X}_{1}\right)$ terhadap kinerja karyawan $\left(\mathrm{X}_{3}\right)$ ditunjukkan oleh $\rho X_{3} X_{1}$ sebesar 0,725 atau $72,5 \%$.

3) Pengaruh motivasi kerja karyawan $\left(\mathrm{X}_{2}\right)$ terhadap kinerja karyawan $\left(\mathrm{X}_{3}\right)$ ditunjukkan oleh $\rho X_{3} X_{2}$ sebesar 0,137 atau $13,7 \%$.

b. Pengaruh tidak langsung

1) Pengaruh promosi jabatan $\left(\mathrm{X}_{1}\right)$ terhadap kinerja karyawan $\left(\mathrm{X}_{3}\right)$ melalui variabel motivasi kerja karyawan $\left(\mathrm{X}_{2}\right)$ ditunjukkan oleh $p X_{2} X_{1} \times \rho X_{3} X_{2}$ sebesar 0,087 atau $8,7 \%$.

\section{Pembahasan \\ Pengaruh Promosi Jabatan terhadap Motivasi Kerja Karyawan}

Hasil penelitian ini sejalan dengan penelitian Prabowo, dkk (2016) yang menyatakan bahwa secara parsial promosi jabatan berpengaruh sigifikan terhadap motivasi kerja Karyawan PT Telkom Indonesia Witel Jatim Selatan Malang. Dengan adanya promosi jabatan pihak perusahaan tentunya berharap agar karyawan mampu mengeluarkan kemampuan terbaiknya yang mungkin selama ini terkendala dikarenakan pada jabatan sebelumnya wewenang karyawan tersebut masih minim. Promosi jabatan yang berdasarkan atas asas keadilan dan obyektifitas akan membuat karyawan 
merasa puas karena mereka merasa bahwa usaha mereka selama ini dihargai oleh pihak perusahaan dan karyawan dapat lebih termotivasi dalam bekerja.

Implikasi yang sebaiknya dilakukan oleh perusahaan adalah sebaiknya perusahaan memberikan kemudahan bagi karyawan dalam proses promosi jabatan secara adil kepada karyawan yang telah bekerja sesuai aturan dan memiliki prestasi yang baik sehingga karyawan akan merasa puas atas apa yang telah diberikan perusahaan kepadanya dan karyawan semakin termotivasi untuk bekerja lebih baik lagi. Melalui program promosi jabatan yang baik juga akan membuat karyawan menjadi memiliki suatu keinginan untuk memenuhi kebutuhannya sendiri dan akan terus melakukan peningkatan kinerjanya di perusahaan.

\section{Pengaruh Promosi Jabatan terhadap Kinerja Karyawan}

Sejalan dengan penelitian yang dilakukan oleh Sabar, dkk (2017) yang menunjukkan bahwa promosi jabatan memiliki pengaruh yang positif dan signifikan terhadap kinerja pegawai Kantor Wilayah Direktorat Jenderal Perbendaharaan Sulawesi Utara. Dengan memiliki karir yang baik dapat membuat dorongan dari dalam diri karyawan tersebut untuk memberikan hasil kerja secara optimal. Karyawan yang memiliki keinginan untuk karir yang lebih baik akan bekerja secara maksimal demi mencapai kebutuhannya dan tujuan perusahaan. Implikasi yang sebaiknnya dilakukan perusahaan adalah dengan memperbanyak posisi yang akan dipromosikan dalam setahun, sebab dengan jumlah posisi yang dipromosikan dalam setahun tidak sebanding dengan jumlah karyawan yang banyak. Selain itu, perusahaan harus tetap mempertahankan kriteria untuk promosi jabatan yaitu senioritas, tingkat pendidikan, dan yang paling utama prestasi kerja. Dalam pelaksanaannya, diperlukan rencana yang matang dan terarah serta dengan pedoman yang jelas dan objektif. Dengan diberlakukannya sistem yang seperti itu, diharapkan karyawan akan meningkatkan kinerjanya untuk dapat meningkatkan jabatannya.

$\begin{array}{llr}\begin{array}{l}\text { Pengaruh } \\ \text { Karyawan } \\ \text { Karyawan }\end{array} & \begin{array}{l}\text { Motivasi } \\ \text { terhaap }\end{array} & \begin{array}{r}\text { Kerja } \\ \text { Kinerja }\end{array} \\ & & \end{array}$

Hal ini sejalan dengan penelitian yang dilakukan oleh Suwardi dan Utomo (2011) yang menyatakan bahwa ada pengaruh motivasi kerja terhadap kinerja pegawai Sekretariat Daerah Kabupaten Pati. Hasil pengujian ini dapat dimaknai bahwa pegawai yang memiliki motivasi kerja yang baik maka kinerjanya akan lebih optimal.

Implikasi yang sebaiknnya dilakukan perusahaan adalah dengan terus memperhatikan kebutuhan dari karyawan, seperti kompensasi diberikan tepat waktu dan tepat sasaran, memberikan fasilitas yang memadai untuk menunjang kinerja karyawan, mengikutsertakan karyawan dalam membuat keputusan yang lebih baik, dan sering mengadakan kegiatan seperti seminar nasional yang mendatangkan motivator agar karyawan merasa semakin termotivasi untuk bekerja sehingga kinerja para karyawan dapat meningkat dan akan berdampak baik untuk perusahaan sendiri. 


\section{SIMPULAN}

Hasil penelitian menunjukkan bahwa promosi jabatan berpengaruh positif terhadap motivasi kerja karyawan. Promosi jabatan berpengaruh terhadap kinerja karyawan dan motivasi kerja karyawan berpengaruh terhadap kinerja karyawan.

\section{DAFTAR PUSTAKA}

Imlawal, T. \&. (2016). Pengaruh Gaji dan Motivasi Kerja terhadap Kinerja Karyawan Players Pool and Lounge. Jurnal Ilmu dan Riset Manajemen Vol. 5 No. 2.

Kadarisman, D. M. (2012). Manajemen Pengembangan Sumber Daya Manusia. Jakarta: PT. Raja Grafindo Persada.

Mangkunegara, A. (2005). Evaluasi Kinerja SDM. Bandung: Refika Aditama.

Prabowo, B. dkk. (2016). Pengaruh Promosi Jabatan Terhadap Motivasi Kerja dan Prestasi Kerja (Studi Pada Karyawan PT Telkom Indonesia Witel Jatim Selatan Malang). Jurnal Administrasi Bisnis (JAB) Vol. 32 No. 1.

Sabar, dkk. (2017). Pengaruh Promosi Jabatan Dan Mutasi Terhadap Kinerja Pegawai (Studi pada Pegawai Kantor Wilayah Direktorat Jenderal Perbendaharaan Provinsi Sulawesi Utara). Jurnal EMBA. Vol.5 No.2. ISSN 2303-1174, Hal. 404 - .413.

Suwardi, \& Utomo, J. (2011). Pengaruh Motivasi Kerja, Kepuasan Kerja, Dan Komitmen Organisasional
Terhadap Kinerja Pegawai (Studi Pada Pegawai Setda Kabupaten Pati). Jurnal Analisis Manajemen. Vol. 5 No. 1. ISSN : 14411-1799.

Wibowo. (2007). Manajemen Kinerja. Jakarta: PT Rajagrafindo Persada. 